\title{
Available Molybdenum Forms Distribution in some Soil Profiles of Different Locations of Southwestern Nigeria.
}

\author{
${ }^{1}$ Oseni, O. A. ${ }^{1}$ Taiwo, A. G., ${ }^{1}$ Ijaola T. O., ${ }^{1}$ Shoyemi,O. S. \\ ${ }^{I}$ Department of Science Laboratory Technology, Chemistry Unit, Moshood Abiola Polytechnic Abeokuta. P.M.B \\ 2210, Ogun State, Nigeria
}

\begin{abstract}
Available molybdenum in soil profiles of twelve (12) different locations of Ogun and Oyo States in South Western Nigeria was investigated to know its status with respect to soil depths. Soil samples derived from sedimentary and igneous/metamorphic rockscomprising of Alfisols (8 profiles) and Ultisols (4 profiles) were collected at four (4) different soil depths of 0-20 cm, 20-40 cm, 40-60 cm and $60-80 \mathrm{~cm}$ respectively from savanna and forest vegetational zones. Soil physic-chemical properties of $\mathrm{pH}$, organic carbon, total nitrogen, CEC, clay, silt, and sand were determined using standard methods and correlated with the available molybdenum. The results showed that available molybdenum was positively correlated with $\mathrm{pH}$, silt and clay $\left(r=0.403^{* *}, r=0.072^{* *}\right.$ and $r$ $\left.=0.025^{* *}\right)$ and also negatively correlated organic carbon, with total nitrogen, CEC and sand $(r=-0.092 * *, r=-$ $0.114^{* *}, r=-0.253^{* *}$ and $\left.r=-0.061^{* *}\right)$ respectively. The status of available Mo fell above the critical limits of 0.05 and 0.1 ppm and as a result, Farmers are advised not to apply molybdenum fertilizers in these soils so as not to cause environmental pollution and soil toxicity.
\end{abstract}

Keywords: Available Molybdenum, Form distribution, Sol Profiles, Alfisols \& Ultisols, Vegetational Zones, Correlation and Critical Limits

\section{Introduction}

One of the most important micronutrients required for plant growth is molybdenum which is known to be essential for $\mathrm{N}_{2}$ fixation by Rhizobia in leguminous crops such as soybeans and groundnuts because it is the component of nitrate reductase enzyme that converts nitrate to nitrite and helps in fixing nitrogen as $\mathrm{NH}_{3}(\mathrm{Jethra}$ andKorthari, 1995). Deficiency symptoms of this element are similar to those of nitrogen.Factors affecting deficiency of this micronutrient in the soil include crop removal, leaching, high soil phosphate, soil compaction cool, wet growing conditions; tie-up in high organic soils, copper deficient soils to mention but a few. Availability of Mo to plants is affected by some soil characteristics such as $\mathrm{pH}$, soil texture, soil moisture, temperature, oxide content, organicmatter content and clay mineralogy (Reisenaueret al., 1973). According to Murphy and Walsh, 1972, Mo deficiencies have been reported for many agronomic crops throughout the world but little or no information is however available on the available Mo in the soils of South Western Nigeria. The present study was carried out to investigate the availableMo status in relation to some soil characteristics of twelve (12) differentlocationsof Southwestern Nigeria.

\section{Sample Collection and Preparation}

\section{Materials And Methods}

Soil samples $(0-20 \mathrm{~cm}, 20-40 \mathrm{~cm}, 40-60 \mathrm{~cm}$ and $60-80 \mathrm{~cm})$ depths, derived from igneous/metamorphic and sedimentary rocks were collected at twelve (12) locations in Southwestern Nigeria from forest and savanna vegetational zones (Table 1 ).

\section{Physico-chemical Analysis}

The samples were analyzed for $\mathrm{pH}$ in 1:1 soil to water slurry. The soil organic carbon was determined by the chromic acid digestion, the soil total nitrogen was determined by macro-kjeldal method, exchangeable cations were extracted with neutral $1 \mathrm{~N} \mathrm{NH}_{4} \mathrm{OAc}, \mathrm{Ca}^{2+}$ and $\mathrm{Mg}^{2+}$ in the extracts were analyzed using an Atomic Absorption Spectrophotometer (AAS) while $\mathrm{K}^{+}$and $\mathrm{Na}^{+}$were determined by a Flame Photometer. The soil CEC was estimated as the sum of the exchangeable cations, the particle size was determined with $\mathrm{KCl}$ and $\mathrm{NH}_{4} \mathrm{OAc}(\mathrm{pH} 4.8$ ) respectively, however, available soil Mo was extracted by acid ammonium oxalate solution, buffered at $\mathrm{pH} 3.3$ (Johnson and Arkeley, 1954) and determined by thiocyanate method as described by Chapman and Pratt, 1961. 
Simple correlations and multiple regressions were calculated between available Mo and soil properties by adopting standard statistical procedures.

\section{Results And Discussion}

\section{Result}

Table 1: General Characteristics of the Soils samples

\begin{tabular}{lllll}
\hline Soil No & Location & Parent Material & Vegetational Zone & Soil Order \\
\hline 1 & Abeokuta & Igneous/Metamorphic & Forest & Alfisol \\
2 & Owode-Egba & Igneous/Metamorphic & Forest & Ultisol \\
3 & Ishaga-Orile & Igneous/Metamorphic & Savanna & Ultisol \\
4 & Ibara-Orile & Igneous/Metamorphic & Savanna & Ultisol \\
5 & Ayetoro & Sedimentary & Savanna & Ultisol \\
6 & Papalanto & Sedimentary & Savanna & Alfisol \\
7 & Ilaro & Sedimentary & Forest & Alfisol \\
8 & Ifo & Sedimentary & Forest & Alfisol \\
9 & Eruwa & Igneous/Metamorphic & Forest & Alfisol \\
10 & Omi-Adio & Igneous/Metamorphic & Forest & Alfisol \\
11 & Idi-Ose & Igneous/Metamorphic & Forest & Alfisol \\
12 & Oyo & Igneous/Metamorphic & Savanna & Alfisol \\
\hline
\end{tabular}

Table 2: Range and Mean values of Physico-chemical properties of Soil samples

\begin{tabular}{|c|c|c|c|c|c|c|c|c|c|c|c|c|c|c|}
\hline \multirow[t]{2}{*}{ Location } & \multicolumn{2}{|c|}{$\mathrm{pH}$} & \multicolumn{2}{|c|}{$\begin{array}{c}\text { Organic Carbon } \\
(\mathrm{g} / \mathrm{kg})\end{array}$} & \multicolumn{2}{|c|}{$\begin{array}{c}\text { Total Nitrogen } \\
(\mathrm{g} / \mathrm{kg})\end{array}$} & \multicolumn{2}{|c|}{$\begin{array}{c}\text { CEC } \\
(\mathrm{Cmol} / \mathrm{kg})\end{array}$} & \multicolumn{2}{|c|}{$\begin{array}{l}\text { Clay } \\
(\%)\end{array}$} & \multicolumn{2}{|c|}{$\begin{array}{l}\text { Silt } \\
(\%)\end{array}$} & \multicolumn{2}{|c|}{$\begin{array}{l}\text { Sand } \\
(\%)\end{array}$} \\
\hline & Range & Mean & Range & Mean & Range & Mean & Range & Mean & Range & Mean & Range & Mean & Range & Mean \\
\hline Abeokuta & $3.90-6.75$ & 5.38 & $0.50-1.50$ & 0.81 & $\begin{array}{l}1.12 \\
3.92\end{array}$ & 2.80 & $1.06-2.59$ & 1.61 & $36.00-46.00$ & 42.75 & $3.70-31.40$ & 13.78 & $32.60-50.30$ & 43.43 \\
\hline Orrode-Egba & $590-7.60$ & 6.30 & $1.24-3.05$ & 2.00 & $7.01-11.98$ & 8.67 & $2006-261$ & 2.30 & $9.40-17.40$ & 12.88 & $5.40-9.40$ & 6.40 & $77.20-85.20$ & 80.73 \\
\hline Ishaga-Orile & 4.80 .5 .80 & 5.51 & $0.60-0.88$ & 0.77 & $\begin{array}{l}2.17 \\
4.62\end{array}$ & 3.47 & 2.67 .3 .80 & 3.10 & $1.40-10.00$ & 6.05 & $6.00-22.00$ & 12.25 & $72.60-92.60$ & 81.70 \\
\hline Ibara-Orile & 5.69 .6 .45 & 5.93 & $0.60-1.04$ & 0.80 & $\begin{array}{l}1.61 \\
2.73\end{array}$ & 2.01 & 2.19 .2 .60 & 2.64 & $\begin{array}{l}5.40 \\
5.60\end{array}$ & 5.45 & Nii & 3.40 & $91.00-91.20$ & 91.15 \\
\hline Ayetoro & 4.67 .5 .50 & 5.17 & 0.94 .1 .32 & 1.09 & $\begin{array}{l}4.13 \\
4.76\end{array}$ & 4.45 & $1.56-3.06$ & 2.00 & $4.00-26.00$ & 12.88 & $5.40-13.40$ & 9.47 & $60.60-90.60$ & 77.65 \\
\hline Papalanto & $5.36-8.26$ & 6.51 & 0.74 .1 .18 & 1.00 & $\begin{array}{l}2.66 \\
4.41\end{array}$ & 3.34 & $2.57-3.02$ & 2.82 & 11.40 .13 .40 & 12.25 & $11.40-17.40$ & 14.15 & $73.20-81.20$ & 76.10 \\
\hline Ilaro & 6.42 .7 .78 & 7.04 & $0.90-1.04$ & 1.00 & $\begin{array}{l}1.75 \\
4.20\end{array}$ & 2.49 & $2.09-2.21$ & 2.14 & $5.40-11.40$ & 7.70 & $2.90-21.40$ & 10.20 & $67.20-89.70$ & 82.10 \\
\hline Ifo & 4.67 .6 .08 & 5.39 & $0.50-1.72$ & 1.24 & $\begin{array}{l}3.71 \\
5.32\end{array}$ & 4.64 & 0.50 .2 .28 & 1.19 & $8.60-32.60$ & 22.95 & $5.40-17.00$ & 9.30 & $59.00-84.00$ & 67.75 \\
\hline Eruira & $5.32 \cdot 6.22$ & 5.79 & $0.48-1.32$ & 0.87 & 1.82 .2 .59 & 2.19 & 2.20 .2 .47 & 2.31 & $4.00-14.00$ & 7.50 & $3.40-18.00$ & 9.83 & $78.00 \cdot 90.60$ & 82.68 \\
\hline Omi-Adio & 6.69 .7 .26 & 7.04 & 0.74 .2 .00 & 1.34 & $2.03-14.50$ & 6.29 & 2.20 .2 .77 & 2.50 & $1.40-27.40$ & 9.70 & $4.00-14.00$ & 7.95 & $58.60-94.60$ & 82.35 \\
\hline Idi-Ose & $6.48-6.84$ & 6.68 & $0.50-1.44$ & 1.04 & $1.75-12.40$ & 5.10 & 2.45 .3 .17 & 2.76 & $1.40-13.40$ & 7.35 & $7.40-12.60$ & 9.75 & $79.20-87.20$ & 82.90 \\
\hline Oyo & $6.05 \cdot 7.07$ & 6.56 & 0.141 .54 & 1.00 & $1.96-11.00$ & 4.55 & 2.12 .2 .58 & 2.33 & $0.60-10.60$ & 3.85 & $12.40-15.40$ & 13.40 & $78.00-86.00$ & 82.75 \\
\hline
\end{tabular}

Table 3: Distribution of available Molybdenum $(\mathrm{mg} / \mathrm{kg})$

\begin{tabular}{lll}
\hline Average Depth $(\mathbf{c m})$ & $\begin{array}{l}\text { Available }- \text { Mo } \\
\text { Range }\end{array}$ & Mean \\
\hline Alfisols (8 profiles) & $1.80-6.30$ & 3.18 \\
$0-20$ & $1.90-6.40$ & 3.79 \\
$20-40$ & $2.80-6.90$ & 4.41 \\
$40-60$ & $2.80-6.80$ & 4.84 \\
$60-80$ & & \\
Ultisol (4 profiles) & $1.60-2.90$ & 2.30 \\
$0-20$ & $2.60-2.90$ & 2.73 \\
$20-40$ & $2.90-3.90$ & 3.38 \\
$40-60$ & $3.60-4.30$ & 3.85 \\
$60-80$ & & \\
\hline
\end{tabular}


Available Molybdenum Forms Distribution in some Soil Profiles of Different Locations of Southwestern

Table 4:Coefficients of Correlation between different Available molybdenum and soil properties

\begin{tabular}{llllllll}
\hline & $\mathbf{p H}$ & Organic - C & Total $-\mathbf{N}$ & CEC & Clay & Silt & Sand \\
\hline Alfisols and Ultisols & & & & & & & \\
Available-Mo & $0.403^{* *}$ & $-0.092^{* *}$ & $0.114^{* *}$ & $-0.253^{* *}$ & $0.072^{* *}$ & $-0.246^{* *}$ & $0.061^{* *}$ \\
& 0.193 & 0.775 & 0.724 & 0.428 & 0.940 & 0.823 & 0.850 \\
\hline
\end{tabular}

Table 5:Regression Coefficients between different Available molybdenum and soil properties

\begin{tabular}{llllllll}
\hline & $\mathbf{p H}$ & Organic $-\mathbf{C}$ & Total $-\mathbf{N}$ & CEC & Clay & Silt & \multicolumn{2}{c}{ Sand } \\
\hline Alfisols and Ultisols & & & & & & & \\
Available - Mo & 0.233 & -0.042 & -0.187 & 0.521 & 0.226 & 0.195 & 44.335 \\
& -5.760 & -7.823 & -25.934 & -0.115 & -48.145 & -4.275 & -0.631 \\
\hline
\end{tabular}

The general characteristics of distribution of the soil samples, the range and the mean values of the physico-chemical properties of soils as well as the available molybdenum in the soils investigated are presented in the tables 1, 2 and 3 respectively. Two main types of soils namely Alfisol and Ultisol occur in the twelve (12) different locations considered. The mean $\mathrm{pH}$ values of most of the soils in these locations were fairly acidic with the exception of Ilaro and Omi -Adio which were considered to be neutral. Owode-Egba soil had the highest organic carbon $(2.00 \mathrm{~g} / \mathrm{kg})$ with the lowest concentration observed for Ishaga-Orile Soil $(0.77 \mathrm{~g} / \mathrm{kg})$. The highest organic carbon found at Owode-Egba soil could be due to the forest vegetation present therein which has resulted in the larger mater litter fall as well as the rate of organic matter decomposition due to microbial activity. Also, the rate of litter fall was very low in Ishaga-Orile soil which has contributed to its low organic carbon content of the soil therein since the location is within the savanna vegetational zone.

Owode-Egba has the highest nitrogen content of $8.67 \mathrm{~g} / \mathrm{kg}$ which was closely followed by Omi-Adio with $6.29 \mathrm{~g} / \mathrm{kg}$, with Ibara-Orile having the lowest of $2.01 \mathrm{~g} / \mathrm{kg}$. However, the highest CEC of $3.10 \mathrm{cmol} / \mathrm{kg}$ was found at Ishaga-Orile whereas the lowest value of $1.19 \mathrm{cmol} / \mathrm{kg}$ was observed for Ifo Soil. It is interesting to report that higher percentages of sand were observed in nearly all the locationsinvestigated with the exception of Abeokuta soil which had $43.43 \%$ of sand but with the highest percentage of clay $(42.75 \%)$ Generally, the distribution of available Mo concentrations through the four (4) soil depths at twelve locations investigated showed consistent increase down the soil profile as the soil depth increased with the exception of Ishaga-Orile and Ilaro which showed irregular trends in their available Mo distribution, Available Mo in the surface soil of both the Alfisol and Utisol ranged from 1.80 to 6.30 and 1.60 to $2.90 \mathrm{mg} / \mathrm{kg}$ with the mean values of 3.18 and $2.30 \mathrm{mg} / \mathrm{kg}$ respectively. Available Mo in all the soils investigated could be considered to be more adequate since $0.05 \mathrm{ppm}$ was regarded as the critical limit for soils above pH 6 (Kanwar and Randhawa, 1978) and also $0.1 \mathrm{ppm}$ was considered as the critical limit for soils with pH 6 (Grigg, 1953). However, since most of the soils in these locations are fairly acidic with the exception of two locations, it would be seen that there was no Mo deficiency in these soils and hence, no Molybdenum nutrition is required in these soils. Available Mo showed weak and very weak positive significant coefficient of correlation with $\mathrm{pH}$, silt and clay (Alfisols and Ultisols, $\mathrm{r}=0.403, \mathrm{r}=0.246$ and $\mathrm{r}=0.072$ ) respectively. It however, showed weak and very weak negative relationships with total nitrogen, CEC, Sand and organic carbon (Table 4). However, the significant values of $0.193,0.775,0.724,0.428,0.940,0.823$ and 0.850 respectively showed that the correlation was insignificant, meaning that these parameters contributed little to the availability of Mo in the soils of these locations.

In multiple regression studies, the available Mo showed significant positive and negative regression coefficients with $\mathrm{pH}, \mathrm{CEC}$, Sand, Silt and Clay $(\mathrm{b}=0.233$ and $-5.760,0.521$ and $-0.115,44.335$ and $-0.631,0.195$ and $-4.275,0.226$ and-48.145) respectively. The multiple regression studies for both the Total $\mathrm{N}$ and Organic Carbon showed significant and negative regression coefficients with available Mo $(b=-0.187$ and $-25.934,-0.042$ and -7.823).

\section{Conclusion}

It could be seen from the results obtained that available molybdenum in the soils of the twelve (12) different locations investigated, increased down the soil profile as the depth increases. Also, soil properties examined contributed both positively and negatively to the available molybdenum concentrations in the soils of these locations. However, the contents of the molybdenum were more than the required level for optimum yield of most leguminous crops so, farmers are advised not to amend the soils therein with molybdenum-containing fertilizer as this would tend to increase the molybdenum concentration in the soil thereby making it to be toxic to both the soil and the plant which can consequently lead to environmental pollution and poses risk to the entire populace in these locations. 


\section{References}

[1] Chapman, H. D. and Pratt, P. F. (1961). Methods of Analysis for soils, Plants and Waters. Division of Agricultural Science, University of California USA.

[2] Grigg, J. L. (1953). Journal of Science Technology 34, 405.

[3] International Institute of Tropical Agriculture (IITA) (1979). Selected methodsfor soil and plant analysis, IITA Manual SeriesNol, Ibadan, Nigeria.

[4] Jethra, J. K and Korthari, M. L (1995). Pro Nat Sem. On developments in Soil Science.

[5] Johnson, C. M. and Arkeley T. N. (1954). Analyt Chem. 26. 572. Journal of Association of Official Analytical Chemists $36,412$.

[6] Kanwar, J. S. and Randhawa, N. S. (1978). Micronutrients Research in Soils and Plants in India, I.C.A.R, New Delhi

[7] Murphy, L. S. and Walsh, L. M. (1972). Correction of micronutrient deficiencies with fertilizers 347 - 387. International Journal. J. Mortredet al., (ed) micronutrients in Agriculture, SSSA, Madison W. I.

[8] Reisenauer, H. M., Walsh, L.M. and Hoeft, R. G. (1973). Testing soils for Sulphur, boron, molybdenum and chlorine. In Walsh, L. M and Beaton, J. D (ed) Soil testing and plant analysis. SSSA Madison, W. I. 173-200. 